\title{
Excision Repair Cross-Complementing
}

\section{Family}

National Cancer Institute

\section{Source}

National Cancer Institute. Excision Repair Cross-Complementing Family. NCI Thesaurus.

Code C105959.

A family of DNA repair proteins. 